\title{
Transport of a Severe Dust Storm in March 2007 and Impacts on Chlorophyll $a$ Concentration in the Yellow Sea
}

\author{
Sai-Chun Tan and Guang-Yu Shi \\ State Key Laboratory of Numerical Modeling for Atmospheric Sciences and Geophysical Fluid Dynamics, \\ Institute of Atmospheric Physics, Chinese Academy of Sciences, Beijing, China
}

\begin{abstract}
The transport process of a severe Asian dust storm event generated in the Gobi Desert during 30-31 March 2007 was examined by several datasets. Results clearly showed that this storm was transported eastward to the northwest Pacific and southeastward to the China seas. Dust particles were deposited in the Yellow Sea accompanied by precipitation on 31 March 2007 and the average deposition flux at an offshore region in the Yellow Sea was $0.56 \mathrm{~g} \mathrm{~m}^{-2} \mathrm{~d}^{-1}$. After 4 days of dust passage over this offshore region, a phytoplankton bloom event appeared on 3 April 2007 and continued until 4-6 April 2007. When compared to non-dust year in 2005, the initial timing of the bloom in 2007 was about 18 days earlier than that in 2005 and peak chlorophyll $a$ concentration in 2007 was $45 \%$ higher than that in 2005. Similar results were found in the dust storm cases in 2004 and 2006. Results indicated that besides increased SST, PAR, and nutrients accumulated in winter from strong mixing, dust input may play important roles in spring bloom in the dust years. That provided evidence of biotic response to natural fertilization caused by dust deposition.
\end{abstract}

\section{Introduction}

The dust aerosols carried by dust storm events in East Asia can be transported to downwind areas through long-range transport (Mikami et al. 2006). Many studies reported that the longrange transport of Asian dust storms to Hong Kong, Taiwan, and the China seas, including the Bohai Sea, the Yellow Sea, the East China Sea, and the South China Sea (Fang et al. 1999; Lin et al. 2007; Yang et al. 2010; Lin et al. 2012), Korea (Chun et al. 2001), Japan (Matsuki et al. 2003), and even the North Pacific and the West Coast of North America (Husar et al. 2001). The marine plankton can be affected by the nutrient-rich dust particles deposited into the oceans, and then it would impact the climate through complex biogeochemical processes (Martin and Fitzwater 1988; Jickells et al. 2005). Many studies proposed that a correlation exited between dust deposition and biological activity and bloom events in the western North Pacific, the Sea of Japan (also known as the East Sea), and the coastal seas of China (Yuan and Zhang 2006; Jo et al. 2007; Han et al. 2011; Tan et al. 2011).

However, few studies have investigated that the supportive evidence of natural eolian iron fertilization on phytoplankton growth directly (Bishop et al. 2002). It is very difficult to measure a complete process of dust generation, transport, deposition and the effects on ocean ecosystem during one dust storm event owing to sporadic property. Meteorological station observation can record the occurring time of dust storm at each station. Conventional satellite can obtain dust aerosol properties (such as aerosol index, aerosol optical depth, etc) throughout the atmosphere, while space-borne lidar measurements (Cloud Aerosol Lidar with Orthogonal Polarization, CALIOP) can provide vertical profiles of dust aerosols.

Combination of meteorological stations and satellite observations and air parcel trajectories, this study analyzed the transport

Corresponding author: Sai-Chun Tan, Institute of Atmospheric Physics, Chinese Academy of Sciences, \#40 Huayanli, Beijing 100029, China. E-mail: sctan@mail.iap.ac.cn. (C2012, the Meteorological Society of Japan. of a severe dust storm occurring in the Gobi Desert (across Mongolia-Inner Mongolia Autonomous Region, China) during 30-31 March 2007 from source to the sea and examined the relationship between dust deposition and phytoplankton bloom in the Yellow Sea; aiming to better understand how phytoplankton grow in response to dust depositions.

\section{Data and methods}

Several datasets have been employed in this study to track the transport process of the dust storm generated in the Gobi Desert during 30-31 March 2007. This dust storm was observed by some meteorological stations in Inner Mongolia and the data were obtained from the National Meteorological Information Center of the China Meteorological Administration. Aerosol index product of Ozone Monitoring Instrument (OMI) onboard Aura satellite (resolution $1^{\circ} \times 1^{\circ}$ ) was used to identify the transport of dust since it provided useful information on the daily spatial distribution of the dust cloud (Husar et al. 2001). It is reported that aerosol index $>2$ can be used to identify the outbreak of dust storms over the Yellow Sea according to comparison with historical record of decades of dust storm episodes (Tan et al. 2011). The CALIOP onboard the Cloud-Aerosol Lidar and Infrared Pathfinder Satellite Observations (CALIPSO) satellite Level 2 Version 3 aerosol profiles products (Winker et al. 2009) were also used. They include both 532 and $1064 \mathrm{~nm}$ aerosol extinction coefficient and particulate depolarization ratio at $532 \mathrm{~nm}$. The vertical resolution was $60 \mathrm{~m}$ below and $180 \mathrm{~m}$ above $20 \mathrm{~km}$, respectively. Dust aerosols could be identified from CALIPSO measurements because dust aerosols have a large depolarization ratio due to their nonsphericity, while the depolarization ratio is near zero for water clouds and other types of aerosols (Huang et al. 2009).

A forward trajectory analysis was performed using the Hybrid Single Particle Lagrangian Integrated Trajectory (HYSPLIT) model (Draxler and Rolph 2010) to examine the transport path of dust storms. Input meteorological data was the National Centers for Environmental Prediction/the National Center for Atmospheric Research (NCEP/NCAR) global reanalysis data with a $2.5^{\circ} \times 2.5^{\circ}$ spatial resolution. An air parcel appearing in the middle of a dust storm event at the source stations was traced forward. In addition, NCEP reanalysis geopotential height, mean sea level pressure and wind speed data were applied to analyze the synoptic pattern during the dust storm.

Chlorophyll $a$ concentrations were used as an indicator for phytoplankton bloom. Sea Surface Temperature (SST) and Photosynthetically Available Radiation (PAR) were used for temperature and light condition for phytoplankton growth, respectively. Both chlorophyll $a$ concentration and PAR data are SeaWiFS Level 3 Standard Mapped Image products with a $9 \times 9 \mathrm{~km}$ spatial resolution. The SST data were Advanced Very High Resolution Radiometer (AVHRR) products and have $4 \times 4 \mathrm{~km}$ spatial resolution. Moreover, Global Precipitation Climatology Project merged daily precipitation data with spatial resolution of $1^{\circ} \times 1^{\circ}$ and monthly averaged ocean surface winds at $10 \mathrm{~m}$ height with $0.25^{\circ} \times 0.25^{\circ}$ spatial resolution from microwave scatterometer QuikSCAT were used to examine the environmental condition. These two datasets were provided by Asia-Pacific Data Research Center at the University of Hawaii (http://apdrc.soest.hawaii.edu). 


\section{Results and discussion}

\subsection{Transport of dust from source regions to the seas}

Asian dust is usually associated with frontal systems and/or cyclones (Tsai et al. 2008). A deep $500 \mathrm{hPa}$ trough extended from about $45^{\circ} \mathrm{N}$ to $25^{\circ} \mathrm{N}$ on 30 March over China (Fig. 1a), indicating the strong intensity of the synoptic system. At the surface, a

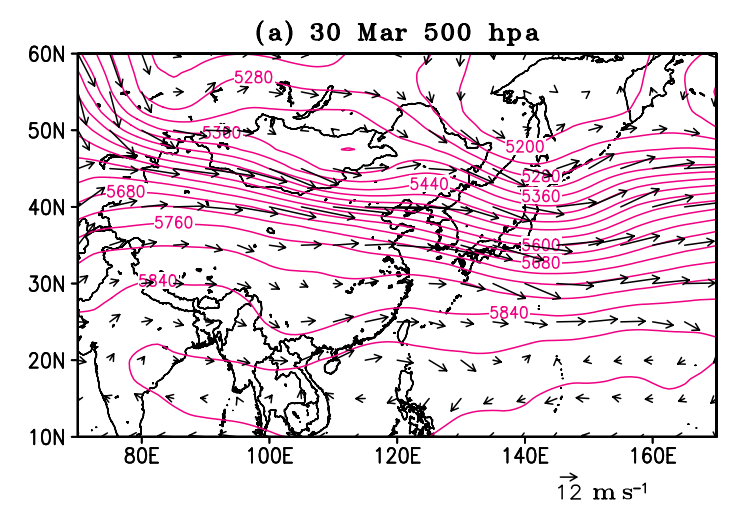

(b) 30 Mar surface

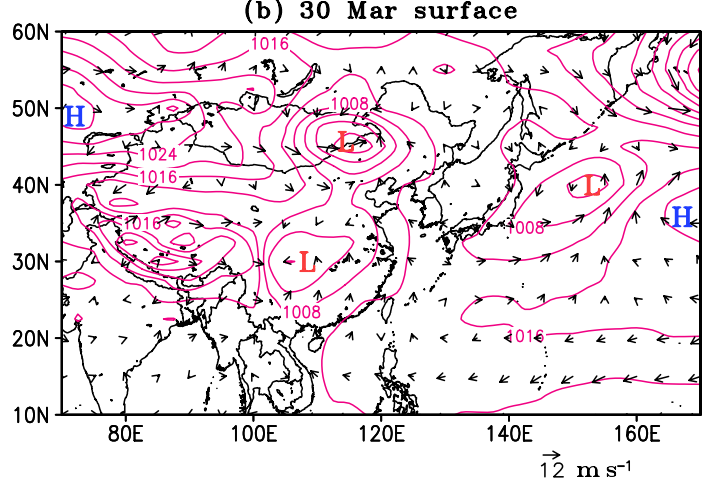

Fig. 1. Synoptic maps at (a) $500 \mathrm{hPa}$ and (b) surface on 30 March 2007. Purple solid lines show geopotential heights in meters at $500 \mathrm{hPa}$ and mean sea level pressures in $\mathrm{hPa}$ at surface. cyclone $(\mathrm{L}=996 \mathrm{hPa})$ was located across the border of the eastern Mongolia and Inner Mongolia and another one $(\mathrm{L}=1004 \mathrm{hPa})$ arrived at the southern China (Fig. 1b). Behind the surface cyclone, there was a high pressure system $(\mathrm{H}=1032 \mathrm{hPa})$. Tsai et al. (2008) indicated that the synoptic pattern with $500 \mathrm{hPa}$ trough and strong surface low center are suitable for dust generation and transport. Thus, such synoptic conditions appeared to be favorable for dust transport southeastward to the China seas and eastward to the northwest Pacific, as supported by the CALIPSO lidar data and forward trajectories (Fig. 2 and Fig. 3).

Meteorological station observations indicated that the dust storm occurred at Guaizihu station in Inner Mongolia at UTC 01:26-04:15 and Sunitezuoqi station in Inner Mongolia at UTC 07:35-12:00 on 30 March 2007, and occurred at Guaizihu at UTC 04:47-06:45 and Sunitezuoqi at UTC 12:00-15:26 on 31 March 2007. Figure 2 shows the average vertical aerosol extinction profiles and particulate depolarization ratio of CALIPSO. The data showed that the dust layer over the source regions, the MongoliaInner Mongolia region (satellite track t1 in Fig. 2a), were mainly located up to $6 \mathrm{~km}$ above mean sea level (Fig. $2 \mathrm{~b}$ and $2 \mathrm{c}$ ). The dust layer peaked at around $0.5 \mathrm{~km}$ and $2 \mathrm{~km}$ with extinction coefficient about $3.7 \mathrm{~km}^{-1}$ and $0.9 \mathrm{~km}^{-1}$, respectively. The dust storm arrived over the Yellow Sea on 31 March (satellite track t2), and the dust particles were located in the altitude from surface to $4 \mathrm{~km}$. The maximum extinction coefficient was $3.4 \mathrm{~km}^{-1}$ at about $0.1 \mathrm{~km}$. The dust storm arrived over the northwest Pacific (satellite track t3) and the South China Sea (satellite track t4) on 3 April. The dust layer was located in $\sim 3-5 \mathrm{~km}$ and $\sim 1-4 \mathrm{~km}$ over the northwest Pacific and the South China Sea, respectively. This result was consistent with the forward trajectories from dust source regions at Guaizihu and Sunitezuoqi stations in Inner Mongolia (Fig. 3). The trajectories showed that the dust storm was transported to the Yellow Sea, the Sea of Japan, the northwest Pacific, the East China Sea, and the South China Sea. Yan et al. (2011) also found this dust storm arrived at Shanghai which is close to the East China Sea on 2 and 3 April.

This typical dust storm processes were also tracked by aerosol index images clearly (Fig. 4). On 30 March 2007, the dust storm was generated in the Gobi Desert. The dust plume was transported to the North and Northeast China and the Yellow Sea after 1 day on 31 March 2007. On 2 April 2007, the dust cloud has passed the Yellow Sea and reached Japan. The dust cloud appeared over the South China Sea and the northwest Pacific on 3 April. a) Satellite track

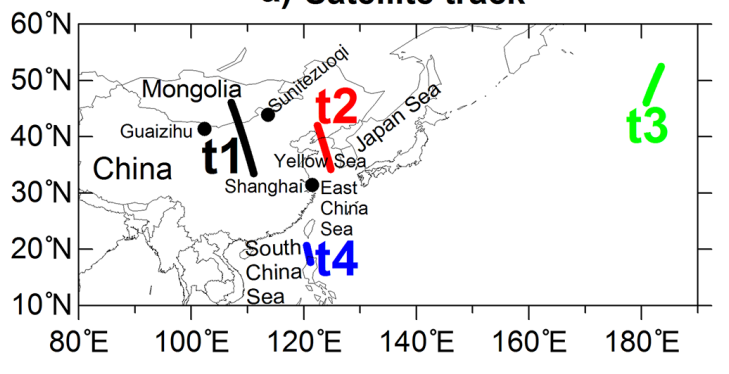

b)

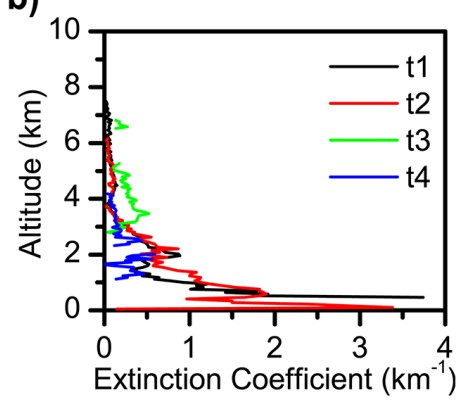

C) Particulate Depolarization Ratio

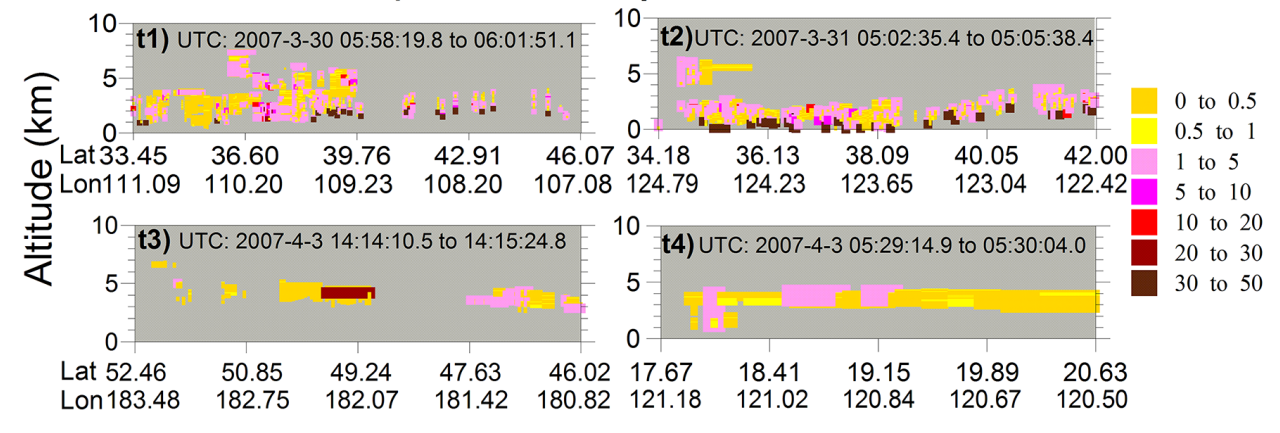

Fig. 2. (a) The location of satellite tracks. (b) The orbit averaged vertical profile of aerosol extinction coefficient for tracks shown in a), the value for track $\mathrm{t} 3$ was multiplied by ten for being recognized clearly. (c) The altitude-orbit crosssection of depolarization ratio for tracks shown in a). The altitude refers to above local mean sea level. 

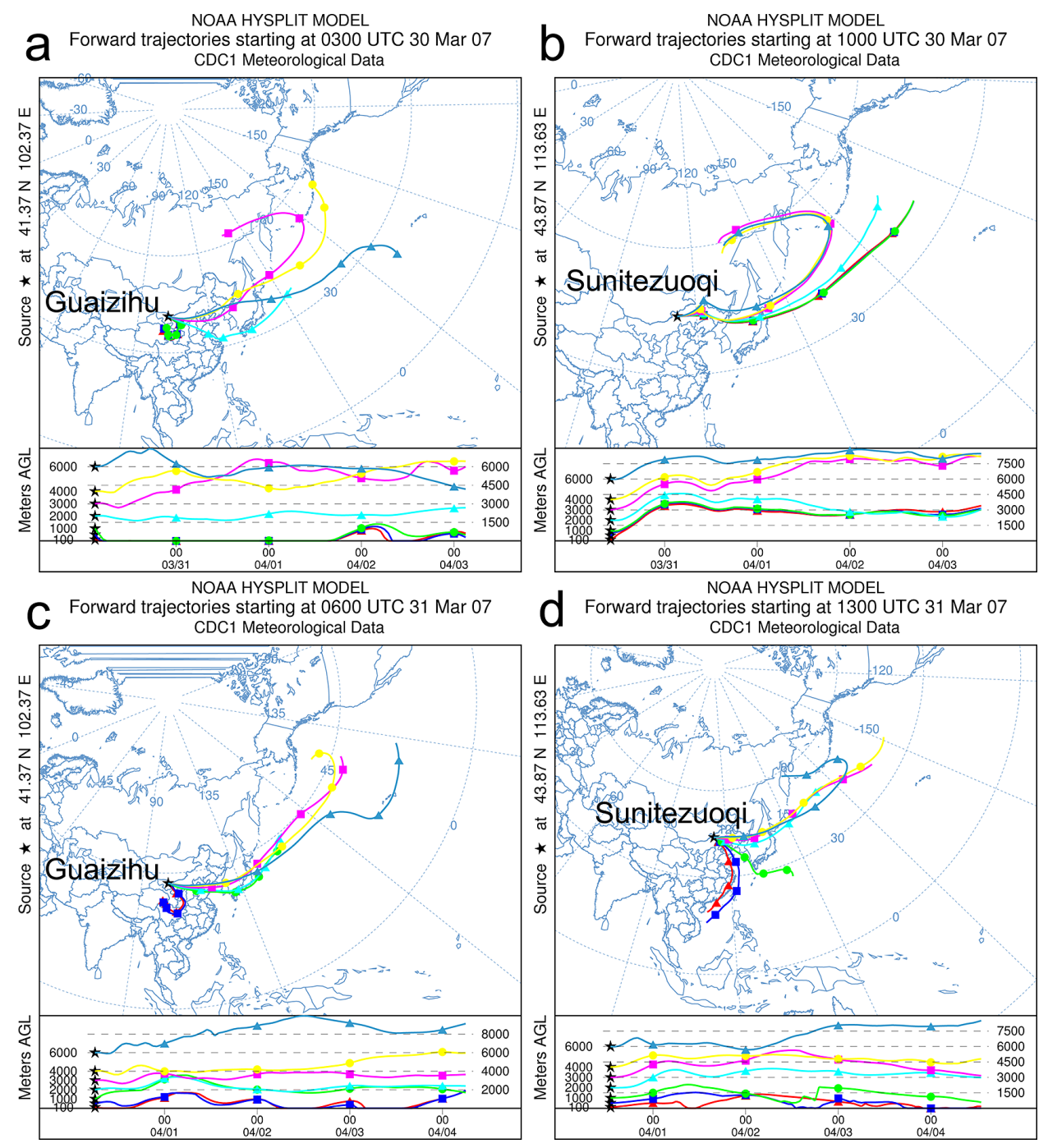

Fig. 3. The 96-hour forward trajectories of air parcels at heights of $100 \mathrm{~m}, 500 \mathrm{~m}$, $1000 \mathrm{~m}, 2000 \mathrm{~m}, 3000 \mathrm{~m}, 4000 \mathrm{~m}$, and $6000 \mathrm{~m}$ over Guaizihu and Sunitezuoqi stations (pentacle in the figure) during the dust event on 30 March 2007 (a and b) and 31 March 2007 (c and d). The top and bottom panels show horizontal and vertical motion, respectively. AGL means above ground level.

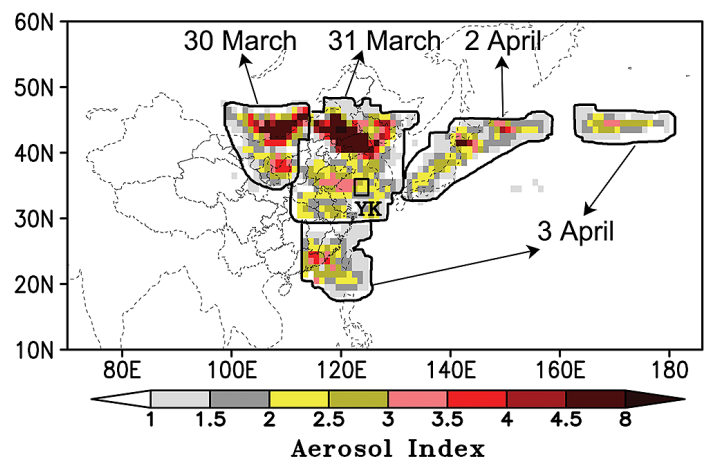

Fig. 4. Approximate location of dust cloud between 30 March and 3 April derived from OMI aerosol index data. YK is a small offshore sampling region $\left(122.5^{\circ} \mathrm{E}-125^{\circ} \mathrm{E}, 33.5^{\circ} \mathrm{N}-36^{\circ} \mathrm{N}\right)$ located in the Yellow Sea.

\subsection{Dust deposition}

Tan et al. (2012) reported a close correlation between dust deposition and aerosol index (AI) over the China seas in spring 2006 , with a relationship of deposition $\left(\mathrm{g} / \mathrm{m}^{2} /\right.$ spring $)=22.292-$ $50.370 \times \mathrm{AI}+28.127 \times \mathrm{AI}^{2}\left(\mathrm{R}^{2}=0.55\right.$, significance $\left.<0.0001\right)$. Dust deposition (including dry and wet depositions) was obtained from the Global/Regional Assimilation and Prediction System/ the Chinese Unified Atmospheric Chemistry Environment for
Dust Atmospheric Chemistry Module (GRAPES/CUACE-Dust) numerical modeling. The model domain covers $70^{\circ} \mathrm{E}-140^{\circ} \mathrm{E}$ and $15^{\circ} \mathrm{N}-60^{\circ} \mathrm{N}$, including the source regions of dust storms in East Asia. Details of the model have been described by Wang et al. (2010). This relationship was then applied to estimate the dust deposition flux on 31 March 2007. A small offshore sampling region $\left(122.5^{\circ} \mathrm{E}-125^{\circ} \mathrm{E}, 33.5^{\circ} \mathrm{N}-36^{\circ} \mathrm{N}\right)$ labeled $\mathrm{YK}$ (Fig. 4) located in the Yellow Sea was selected in order to examine the response of phytoplankton to dust deposition in the following section. The average deposition flux in YK region was $0.56 \mathrm{~g} \mathrm{~m}^{-2} \mathrm{~d}^{-1}$, which included dry and wet depositions because of $8.9 \mathrm{~mm}$ rainfall amount appearing on that day. The mean dry deposition flux over the Yellow Sea on 24 April 2006 estimated by a two layers model was about $0.44 \mathrm{~g} \mathrm{~m}^{-2} \mathrm{~d}^{-1}$ (Yang et al. 2010), which is comparable to our result.

\subsection{Chlorophyll a concentration in response to dust deposition}

Daily chlorophyll a concentrations in YK region before, during and after the dust storm are shown in Fig. 5. SST, PAR, and aerosol index during the same period are also shown. The initiation of spring bloom was defined as chlorophyll $a$ concentration $>3 \mathrm{mg} \mathrm{m}^{-3}$, which is twice the average in the winter of 20042007.

It was clearly shown in Fig. 5a that aerosol index on 31 March 2007 was higher than the other days. Before dust deposition, chlorophyll $a$ concentration was lower than bloom level and the largest value was only $1.9 \mathrm{mg} \mathrm{m}^{-3}$ (Fig. 5b). After 4 days of dust deposition, a phytoplankton bloom event appeared during 4-6 

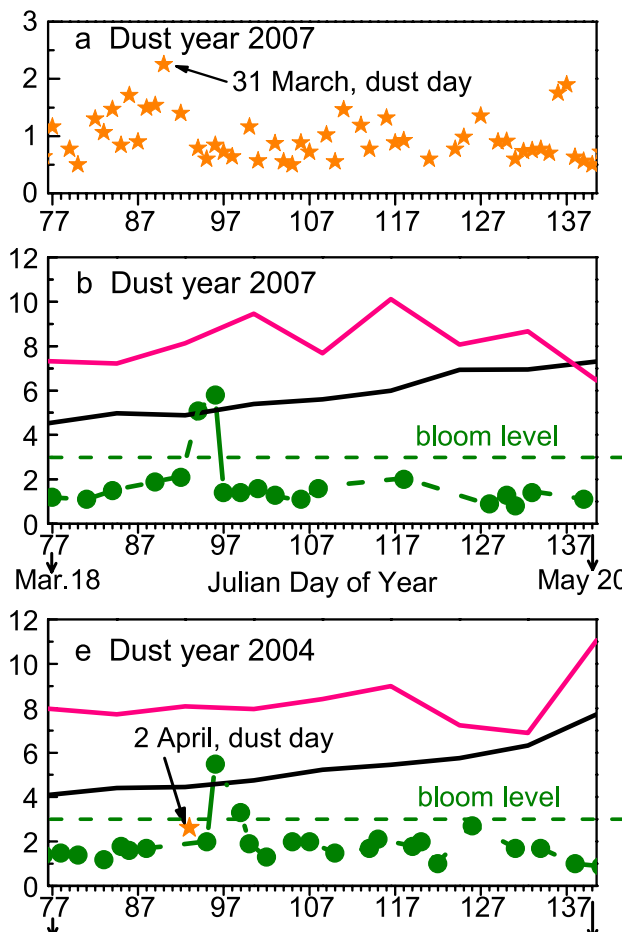

Mar.17 Julian Day of Year

* aerosol index

$\longrightarrow$ daily chlorophyll a concentration $\left(\mathrm{mg} \mathrm{m}^{-3}\right)$
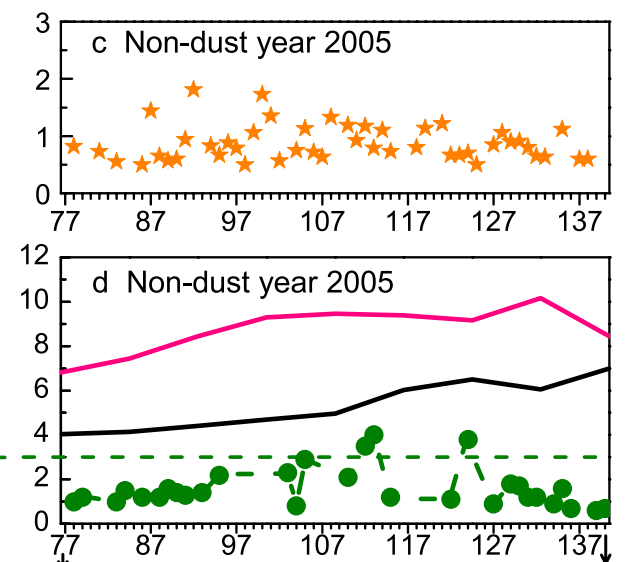

Mar.18 Julian Day of Year May 20

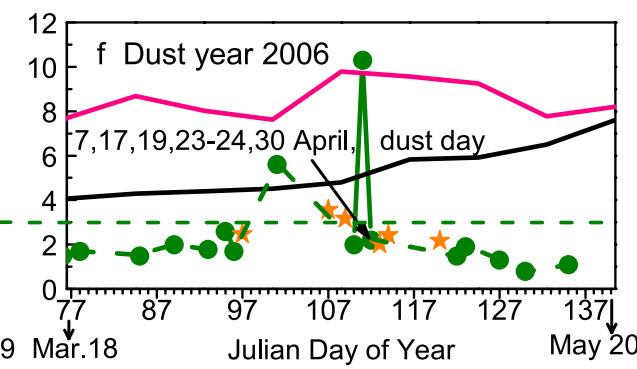

PAR/5 (Ein $\left.\mathrm{m}^{-2} \mathrm{~d}^{-1}\right)$

Fig. 5. Variations in daily aerosol index, daily chlorophyll a concentration, and 8-day surface PAR and SST in the YK region from 18 March through 20 May. Dash line shows the bloom level defined as chlorophyll $a$ concentration is $3 \mathrm{mg} \mathrm{m}^{-3}$ (twice as large as winter average).

April 2007. Chlorophyll $a$ concentration increased to $5.8 \mathrm{mg} \mathrm{m}^{-3}$ on 6 April 2007, and then decreased to lower than $1.6 \mathrm{mg} \mathrm{m}^{-3}$ after 7 April 2007. In comparison with 2007, no dust events occurred during the same period in 2005. Aerosol index was lower than 1.8 in 2005 (Fig. 5c). Chlorophyll $a$ concentration showed that a bloom event occurred on 22 April with a peak value of $4.0 \mathrm{mg} \mathrm{m}^{-3}$ (Fig. 5d). The bloom event in 2007 developed about 18 days earlier than non-dust event year in 2005 and peak chlorophyll $a$ concentration in 2007 was $45 \%$ higher than 2005 .

In addition, the dust storm cases in 2004 (Fig. 5e) and 2006 (Fig. 5f) were also taken into account as an additional support. Similarly, the peak chlorophyll $a$ concentration in 2004 was $38 \%$ higher than 2005 and the timing of bloom in 2004 was 17 days earlier. The peak chlorophyll $a$ concentration in 2006 was about 2.6 times that in 2005 and the timing of bloom was 11 days earlier than 2005. The lag time of bloom relative to dust passage was $2-4$ days in 2004 and 2006. A lag of several days was reasonable as aerosol iron dissolution could take place in short-term (minutes to hours) or long-term (days to weeks) within the euphotic zone (Boyd et al. 2010), which was comparable to 5-10 days' lag in the Sea of Japan (Jo et al. 2007).

During the research period in the dust years and non-dust year, PAR was higher than 34 Ein $\mathrm{m}^{-2} \mathrm{~d}^{-1}$ and SST was over $8^{\circ} \mathrm{C}$. First, high SST and PAR are very important for spring bloom in the dust years owing to the lowest SST in the dust years was $1-12 \%$ higher than that in 2005 and PAR was 6-13\% higher than that in 2005. Second, nutrients are another important limiting factor for phytoplankton growth. Region YK was far from the impact region of the Yangtze River diluted water in spring according to Wang et al. (2003). From spring to late fall, the existence of thermocline and pycnocline constrained the transport of nutrients from bottom to surface (Wang 2000). Model simulations indicated that strong winter mixing affecting nutrients supply from deep waters to surface waters is prerequisite to spring bloom in the central southern Yellow Sea (Tian et al. 2005). The mean wind speed from December in last year to next year March in $2005\left(8.3 \mathrm{~m} \mathrm{~s}^{-1}\right)$ was higher than that in $2004\left(7.5 \mathrm{~m} \mathrm{~s}^{-1}\right)$ and $2007\left(7.3 \mathrm{~m} \mathrm{~s}^{-1}\right)$ and comparable to $8.4 \mathrm{~m} \mathrm{~s}^{-1}$ in 2006, which indicated that mixing due to winter monsoon in the dust years was not stronger than nondust year. That suggests besides increased SST, PAR, and nutrients accumulated in winter from strong winter mixing, dust deposition may also play important roles in spring bloom in the dust years.

The southern central Yellow Sea could be limited by macronutrients (nitrogen and phosphorus) and micronutrients (such as iron) according to previous studies (Zou et al. 2000; Wang et al. 2003). Dust storm could provide more nitrogen in the Yellow Sea in spring because the concentrations of organic nitrogen in dust aerosols significantly increased during dust storm events (Shi et al. 2010). In addition, dust deposition associated with precipitation may deliver more iron in the dust years due to higher solubitlity (Spokes et al. 1994), especially in 2007. YK region has low rainfall $(0.02 \mathrm{~mm})$ on the dust day in 2004 and only $0.2 \mathrm{~mm}$ rainfall on 17 April 2006 among the six dust deposition days (Fig. 5f) and $8.9 \mathrm{~mm}$ rainfall appeared on the dust day in 2007. Jo et al. (2007) also indicated that wet dust deposition played an important role in the spring bloom in the Sea of Japan.

It was needed to be noted that not all dust inputs would induce bloom. There was no bloom occurring after the passage of the dust storms on 23-24 April 2006 and 30 April 2006. It was likely because the PAR decreased after passage of these dust events (Fig. 5f) and dust particles transported at higher altitude deprived of nutrients accruement (Tan et al. 2011).

\section{Conclusions}

We report the transport processes of a severe dust storm event generated in the Gobi Desert during 30-31 March 2007 based on meteorological stations and satellite observations and trajectory analysis. Results indentified that dust particles were transported from source regions to the downwind seas, including the Yellow Sea and the northwest Pacific Ocean. The deposition flux was estimated to $0.56 \mathrm{~g} \mathrm{~m}^{-2} \mathrm{~d}^{-1}$ in the Yellow Sea on 31 March 2007 according to an empirical formula.

Based on dust deposition, the relationship of dust with phytoplankton bloom in the Yellow Sea was investigated. Results show 
that bloom could be initiated after several days' passage of dust events in the Yellow Sea, which strongly implicates the possibility that eolian dust sometimes associates with precipitation providing bio-available nutrients such as nitrogen and iron to the ocean. When compared to the situation in non-dust year, the timing of bloom in dust years were about two weeks earlier than non-dust year and peak chlorophyll $a$ concentrations in dust years were also higher than that in non-dust year. In agreement with previous studies (e.g., Bishop et al. 2002) the results of this work provide a direct support to the natural fertilization owing to dust deposition.

\section{Acknowledgements}

The authors would like to thank the National Natural Science Foundation of China (Grant No. 41005080 and 41130104) and the International Cooperative Projects of MOST (Grant No. 2010DFA22770) for funding this study.

\section{References}

Bishop, J. K. B., R. E. Davis, and J. T. Sherman, 2002: Robotic observations of dust storm enhancement of carbon biomass in the North Pacific. Science, 298, 817-821.

Boyd, P. W., D. S., Mackie, and K. A. Hunter, 2010: Aerosol iron deposition to the surface ocean - Modes of iron supply and biological responses. Marine Chemistry, 120, 128-143.

Chun, Y., K.-O. Boo, J. Kim, S.-U. Park, and M. Lee, 2001: Synopsis, transport, and physical characteristics of Asian dust in Korea. $J$. Geophys. Res., 106, 18461-18469.

Draxler, R. R., and G. D. Rolph, 2010: HYSPLIT (HYbrid SingleParticle Lagrangian Integrated Trajectory) Model access via NOAA ARL READY Website (http://ready.arl.noaa.gov/ HYSPLIT.php). NOAA Air Resources Laboratory, Silver Spring, MD (accessed 2012.7.26).

Fang, M., M. Zheng, F. Wang, K. S. Chim, and S. C. Kot, 1999: The long-range transport of aerosols from northern China to Hong Kong - a multi-technique study. Atmos. Environ., 33, 18031817.

Han, Y., T. Zhao, L. Song, X. Fang, Y. Yin, Z. Deng, S. Wang, and S. Fan, 2011: A linkage between Asian dust, dissolved iron and marine export production in the deep ocean. Atmos. Environ., 45, 4291-4298.

Huang, J., Q. Fu, J. Su, Q. Tang, P. Minnis, Y. Hu, Y. Yi, and Q. Zhao, 2009: Taklimakan dust aerosol radiative heating derived from CALIPSO observations using the Fu-Liou radiation model with CERES constraints. Atmos. Chem. Phys., 9, 4011-4021.

Husar, R. B., D. M. Tratt, B. A. Schichtel, S. R. Falke, F. Li, D. Jaffe, S. Gassó, T. Gill, N. S. Laulainen, F. Lu, M. C. Reheis, Y. Chun, D. Westphal, B. N. Holben, C. Gueymard, I. McKendry, N. Kuring, G. C. Feldman, C. McClain, R. J. Frouin, J. Merrill, D. DuBois, F. Vignola, T. Murayama, S. Nickovic, W. E. Wilson, K. Sassen, N. Sugimoto, and W. C. Malm, 2001: Asian dust events of April 1998. J. Geophys. Res., 106, 18317-18330.

Jickells, T. D., Z. S. An, K. K. Andersen, A. R. Baker, G. Bergametti, N. Brooks, J. J. Cao, P. W. Boyd, R. A. Duce, K. A. Hunter, H. Kawahata, N. Kubilay, J. laRoche, P. S. Liss, N. Mahowald, J. M. Prospero, A. J. Ridgwell, I. Tegen, and R. Torres, 2005: Global iron connections between desert dust, ocean biogeochemistry, and climate. Science, 308, 67-71.

Jo, C.-O., J.-Y. Lee, K.-A. Park, Y.-H. Kim, and K.-R. Kim, 2007: Asian dust initiated early spring bloom in the northern East/ Japan Sea. Geophys. Res. Lett., 34, L05602, doi:05610.01029/ 02006 GL027395.

Lin, C. Y., Y. F. Sheng, W. N. Chen, Z. Wang, C. H. Kuo, W. C. Chen, and T. Yang, 2012: The impact of channel effect on Asian dust transport dynamics: a case in southeastern Asia. Atmos. Chem. Phys., 12, 271-285.

Lin, I.-I., J.-P. Chen, G. T. F. Wong, C.-W. Huang, and C.-C. Lien, 2007: Aerosol input to the South China Sea: Results from the MODerate Resolution Imaging Spectro-radiometer, the Quick Scatterometer, and the Measurements of Pollution in the Troposphere Sensor. Deep Sea Res., Part II, 54, 1589-1601, doi: 1510.1016/j.dsr1582.2007.1505.1013.

Martin, J. H., and S. E. Fitzwater, 1988: Iron deficiency limits phytoplankton growth in the north-east Pacific subarctic. Nature, 331, 341-343.

Matsuki, A., Y. Iwasaka, K. Osada, K. Matsunaga, M. Kido, Y. Inomata, D. Trochkine, C. Nishita, T. Nezuka, and T. Sakai, 2003: Seasonal dependence of the long-range transport and vertical distribution of free tropospheric aerosols over east Asia: On the basis of aircraft and lidar measurements and isentropic trajectory analysis. J. Geophys. Res., 108, 8663-8676, doi:8610.1029/2002 JD003266.

Mikami, M., G. Y. Shi, I. Uno, S. Yabuki, Y. Iwasaka, M. Yasui, T. Aoki, T. Y. Tanaka, Y. Kurosaki, K. Masuda, A. Uchiyama, A. Matsuki, T. Sakai, T. Takemi, M. Nakawo, N. Seino, M. Ishizuka, S. Satake, K. Fujita, Y. Hara, K. Kai, S. Kanayama, M. Hayashi, M. Du, Y. Kanai, Y. Yamada, X. Y. Zhang, Z. Shen, H. Zhou, O. Abe, T. Nagai, Y. Tsutsumi, M. Chiba, and J. Suzuki, 2006: Aeolian dust experiment on climate impact: An overview of Japan-China joint project ADEC. Global and Planetary Change, 52, 142-172.

Shi, J., H. Gao, J. Qi, J. Zhang, and X. Yao, 2010: Sources, compositions, and distributions of water-soluble organic nitrogen in aerosols over the China Sea. J. Geophys. Res., 115, D17303, doi:17310.11029/12009JD013238.

Spokes, L. J., T. D. Jickells, and B. Lim, 1994: Solubilisation of aerosol trace metals by cloud processing: A laboratory study. Geochimica et Cosmochimica Acta, 58, 3281-3287.

Tan, S.-C., G.-Y. Shi, J.-H. Shi, H.-W. Gao, and X. Yao, 2011: Correlation of Asian dust with chlorophyll and primary productivity in the coastal seas of China during the period from 1998 to 2008. J. Geophys. Res., 116, G02029, doi:02010.01029/02010JG001456.

Tan, S.-C., G.-Y. Shi, and H. Wang, 2012: Long-range transport of spring dust storms in Inner Mongolia and impact on the China seas. Atmos. Environ., 46, 299-308.

Tian, T., H. Wei, J. Su, and C. Chung, 2005: Simulations of annual cycle of phytoplankton production and the utilization of Nitrogen in the Yellow Sea. Journal of Oceanography, 61, 343-357.

Tsai, F., G. T.-J. Chen, T.-H. Liu, W.-D. Lin, and J.-Y. Tu, 2008: Characterizing the transport pathways of Asian dust. J. Geophys. Res., 113, D17311, doi:17310.11029/12007JD009674.

Wang, B. D., 2000: Characteristics of variations and interrelations of biogenie elements in the Yellow Sea cold water mass. Acta Oceanologica Sinica, 22, 47-54, (in Chinese).

Wang, B.-D., X.-L. Wang, and R. Zhan, 2003: Nutrient conditions in the Yellow Sea and the East China Sea. Estuarine, Coastal and Shelf Science, 58, 127-136.

Wang, H., S.-L. Gong, H.-L. Zhang, Y. Chen, X.-S. Shen, D. Chen, J. Xue, Y.-F. Shen, X.-J. Wu, and Z.-Y. Jin, 2010: A new-generation sand and dust storm forecasting system GRAPES CUACE/ Dust: model development, verification and numerical simulation. Chinese Sci. Bull., 55, 635-649.

Winker, D. M., M. A. Vaughan, A. Omar, Y. Hu, K. A. Powell, Z. Liu, W. H. Hunt, and S. A. Young, 2009: Overview of the CALIPSO mission and CALIOP data processing algorithms. J. Atmos. Oceanic Technol., 26, 2310-2323.

Yan, P., Z. Wang, X. Wang, Q. Fu, and Q. Wang, 2011: Impact of pollutant transport on the air quality of Shanghai in 2007. SOLA, 7, 85-88.

Yang, D.-X., Y. Liu, and W.-Z. Chen, 2010: Estimation of the total dust column and dry deposition flux over the Yellow Sea, China based on shipboard sun photometer measurements: Case study. Atmos. Ocean. Sci. Lett., 3, 64-69.

Yuan, W., and J. Zhang, 2006: High correlations between Asian dust events and biological productivity in the western North Pacific. Geophys. Res. Lett., 33, L07603, doi:07610.01029/02005GL 025174.

Zou, L., H. T. Chen, and J. Zhang, 2000: Experimental examination of the effects of atmospheric wet deposition on primary production in the Yellow Sea. J. Exp. Mar. Biol. Ecol., 249, 111-121.

Manuscript received 21 May 2012, accepted 26 July 2012

SOLA: http://www.jstage.jst.go.jp/browse/sola 